BALENA, L; MALANCHUK, JP; TAMANINI JUNIOR, C; RIBAS, EL; ESCHEMBACK, V; KAWAKAMI, J. 2021. Growth, yield and dormancy of aeroponically produced potato minitubers as a function of planting density and harvesting date. Horticultura Brasileira 39: 161-168. DOI: http://dx.doi. org/10.1590/s0102-0536-20210206

\title{
Growth, yield and dormancy of aeroponically produced potato minitubers as a function of planting density and harvesting date
}

\author{
Leonardo Balena ${ }^{1} \mathbb{D}$; João Pedro Malanchuk ${ }^{2} \mathbb{D}$; Cleto Tamanini Junior ${ }^{2} \mathbb{D}$; Erica L Ribas ${ }^{3} \mathbb{D}$; Vlandiney \\ Eschemback $^{2} \mathbb{D}$; Jackson Kawakami ${ }^{2} \mathbb{D}$
}

${ }^{1}$ Escola Superior de Agricultura “Luiz de Queiroz” (ESALQ-USP), Piracicaba-SP, Brasil; lbalena93@gmail.com; ${ }^{2}$ Universidade Estadual do Centro-Oeste do Paraná (Unicentro), Guarapuava-PR, Brasil; malanchukjp@gmail.com; junior_tamanini@hotmail.com; veschemback@ hotmail.com; jkawa13@hotmail.com; ${ }^{3}$ Centro Universitário Campo Real, Guarapuava-PR, Brasil, eng-ericaribas@camporeal.edu.br

\begin{abstract}
Potato seed is one of the largest costs of a crop. This is mostly due to the incidence and spread of viruses that occurs when the crop is grown in the open field. Thus, it is necessary to obtain virusfree potato plantlets through meristem isolation, with subsequent cultivation in a protected environment, where it is easier to control virus-spreading insects. One way to increase greenhouse viability is by multiplicating potato seed using high technology systems, among them, aeroponics. The objective of this work was to determine the effect of planting density on the growth and yield of potato plants cv. Agata in aeroponic cultivation, and the effect of harvesting dates and planting densities on the dormancy of harvested minitubers. The number of stems, leaves, and the number and fresh weight of minitubers/plant reduced when planting density was increased from 60 to 180 plants $/ \mathrm{m}^{2}$. However, the number of stems, leaves, initiated minitubers, and the number and fresh weight of minitubers/ $\mathrm{m}^{2}$ increased when planting density was increased from 60 to 180 plants $/ \mathrm{m}^{2}$. The maximum number of type III minitubers $(>30 \mathrm{~mm})$ was $613 / \mathrm{m}^{2}$, obtained at the density of 180 plants $/ \mathrm{m}^{2}$. Plant density did not affect the dormancy of harvested minitubers, but harvesting date did. Minitubers obtained from latter harvesting dates had a shorter dormancy period. Minitubers harvested at 78 and 64 days after transplanting sprouted 21 and seven days earlier than those picked at 50 days after transplanting.
\end{abstract}

Keywords: Solanum tuberosum, aeroponics, hydroponics, potato seed.

\section{RESUMO}

Crescimento, produtividade e dormência de minitubérculos de batata produzidos por aeroponia em função da densidade de plantio e data de colheita

A batata semente é um dos maiores custos de uma lavoura. Isso se deve principalmente à incidência e disseminação de vírus que ocorre no cultivo a campo. Assim, se torna necessária a obtenção de plântulas de batata livres de vírus através do isolamento de meristemas, com o cultivo subsequente em ambiente protegido, onde há maior controle de insetos vetores de vírus. Uma forma de aumentar a viabilidade do ambiente protegido é com a multiplicação em sistemas de alta tecnologia, dentre eles, a aeroponia. O objetivo desse trabalho foi determinar o efeito da densidade de plantio no crescimento e na produtividade de plantas de batata cv. Agata no cultivo aeropônico, e o efeito da data de colheita e densidade de plantio sobre a dormência dos minitubérculos colhidos. O número de hastes, folhas, e o número e peso fresco de minitubérculos/planta reduziram quando a densidade de plantio foi aumentada de 60 para 180 plantas $/ \mathrm{m}^{2}$. Entretanto, o número de hastes, folhas, minitubérculos iniciados, e o número e peso fresco de minitubérculos $/ \mathrm{m}^{2}$ aumentou quando a densidade de plantio foi aumentada de 60 para 180 plantas $/ \mathrm{m}^{2}$. A máxima taxa de multiplicação de minitubérculos do tipo III (>30 mm; 13,9 g) foi de $613 / \mathrm{m}^{2}$, obtida na densidade de 180 plantas $/ \mathrm{m}^{2}$. A densidade de plantio não afetou a dormência dos minitubérculos colhidos, mas a data de colheita sim. Minitubérculos colhidos nas últimas colheitas tiveram período de dormência menor. Minitubérculos colhidos aos 64 e 78 dias após o transplantio brotaram 21 e sete dias mais cedo do que aqueles colhidos aos 50 dias após o transplantio.

Palavras-chave: Solanum tuberosum, aeroponia, hidroponia, batata semente.

Received on July 27, 2020; accepted on April 21, 2021

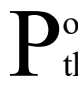
otato (Solanum tuberosum) is the third most important crop for human consumption. In 2018, 368 million tons of this crop were produced in the world, from which 3.68 million $\mathrm{t}$ were produced in Brazil (FAO, 2020). Among Brazilian states, Paraná is the third-largest producer, detaining $20 \%$ of the national production (IBGE-
LSPA, 2020). In Paraná, the region of Guarapuava accounts for almost $1 / 4$ of total production $(219000 \mathrm{t})(\mathrm{SEAB}$, 2019).

As a costly product, due mainly to its high level of degeneration, potato seed can account for up to $20 \%$ of total production cost (CEPEA/ESALQ/ USP, 2019). Brazilian farmers spend, annually, around U\$ 7 million with the importation of this input (CEPII, 2020).

One way in which countries from tropical regions can reduce the potato seed cost and importation from other countries, is by structuring systems for the certification and production of greenhouse-grown potato seed, where propagation of virus among plants 
through insect-vectors is controlled (FAO, 2008; Muthoni et al., 2013). That kind of cultivation can become expensive due to the construction cost of the greenhouse. Thus, techniques and systems that increase plant multiplication rates, e.g. hydroponics and aeroponics, must be researched in order to make the greenhouse structure viable (Mateus-Rodríguez et al., 2013).

One of the most efficient ways of producing first-generation potato seed minitubers in greenhouses is through aeroponics (Mateus-Rodríguez et al., 2013). In this system, potato plants are placed upon a module, inside of which roots receive intermittent aspersions of nutrient solution (Andrade-Piedra et al., 2015). Shoot and leaves grow above that module. The opening of side windows allows the sequential harvest of minitubers. When minitubers are picked early, photo-assimilates are redirected to new tubers, favoring the multiplication rate over the increase in fresh weight of minitubers (Factor et al., 2007). In that manner, aeroponics allows higher multiplication rates/plant and $/ \mathrm{m}^{2}$ than other systems, such as cultivation DFT (Deep Flow Technique) and NFT (Nutrient Film Technique) hydroponic systems, and in pots (Factor et al., 2007; Mateus-Rodríguez et al., 2013).

In recent studies with the aeroponic technique, it was observed that cvs. Agata and Asterix respond positively to the increase in planting density from 25 to $100 \mathrm{plants} / \mathrm{m}^{2}$, at the winter/spring and autumn/winter crop seasons in northern Sao Paulo (Calori et al., 2017, 2018). However, Farran \& Mingo-Castel (2006), working with cv. Zorba in Spain, obtained a contrary response; that is, the density of 60 plants $/ \mathrm{m}^{2}$ had higher yields than the density of 100 plants $/ \mathrm{m}^{2}$, when weekly harvested. These results suggest that there may be an interaction among planting density, growing season, and growing region, so that more studies are necessary in order to define the best planting density in each region and season. Also, there are no reports on the effect of plant densities higher than 100 plants $/ \mathrm{m}^{2}$ in the literature, needing further investigation.

Another aspect of aeroponic production involving minituber physiology is the storage and dormancy period of minitubers obtained at different harvesting dates. Minitubers of cv. Ametyst harvested at different dates had different physiological ages and varying tuber yields in the field (Rykaczewska, 2016). Therefore, there may be variation in the dormancy period of minitubers harvested at different dates, which would have implications for crop management.

In Brazil, 'Agata' (BM $5272 \mathrm{x}$ Sirco), early and high-yielding cultivar (SASA, 2020), is the most planted, accounting for $55 \%$ of the total harvested area in 2010 (ABBA, 2010). Thus, the objective of this work was to evaluate the growth and yield of potato plants cv. Agata in aeroponic cultivation, at different planting densities, in the autumn growing season; and to evaluate the dormancy of harvested minitubers, as a function of harvesting dates and planting densities.

\section{MATERIAL AND METHODS}

\section{Planting densities}

The experiment was carried out in a greenhouse equipped with a cooling system composed of an evaporative panel and a fan-extractor, in Guarapuava city, state of Paraná $\left(25^{\circ} 23^{\prime} 01^{\prime}\right.$ 'S, $51^{\circ} 29^{\prime} 39^{\prime \prime} \mathrm{W}, 1100 \mathrm{~m}$ above sea level). The aeroponic system was built according to the recommendations from the International Potato Center, using timber, polystyrene sheets (EPS) and canvas as constructive elements of the module (Otazú, 2010; Andrade-Piedra et al., 2015), with adaptations only to the aspersion system (Factor, 2007).

Virus-free, micropropagated plantlets were acquired from a commercial tissue culture laboratory (TOR Biotecnologia, Castro-PR). Transplantation to the aeroponic module was carried out on March 1 $1^{\text {st }}, 2018$. Plantlets were detached from substrate through immersion in running water, then placed in inert polyurethane foam (D33 density), and transplanted to the aeroponic module, under the protection of a thermoreflective cloth (Aluminet ${ }^{\circledR}$ $50 \%$ ).

Until fifteen days of cultivation, the electrical conductivity of the nutrient solution was maintained at $0.7 \mathrm{dS} / \mathrm{m}$ and the aspersion set to 1 minute "on" and 2 minutes "off", to establish the recently transplanted plantlets. On the remainder of the growing cycle, aspersion set to 2 minutes on and 6 minutes off.

The nutrient solution was formulated according to Medeiros et al. (2002), with $2.2 \mathrm{dS} / \mathrm{m}$ electrical conductivity and $\mathrm{pH}$ of 6 . The conductivity and $\mathrm{pH}$ were calibrated every three days. Measurements were taken using handheld conductivity $\left(\mathrm{AKSO}^{\circledR}, \mathrm{AK} 50\right)$ and $\mathrm{pH}\left(\mathrm{AKSO}^{\circledR}, \mathrm{AK} 95\right)$ meters. EC calibration was done using stock solutions of macronutrients, calcium nitrate and micronutrients, whereas $\mathrm{pH}$ calibration was done using phosphoric acid and sodium hydroxide. The nutrient solution was replaced every fifteen days to maintain the nutrient solution balanced. Pests and diseases were monitored visually, and, when necessary, usual regional control practices (e.g. fungicide and insecticide spray) were adopted.

$\mathrm{Cv}$. Agata plantlets were transplanted at five densities: 60, 90, 120, 150, and 180 plants $/ \mathrm{m}^{2}$, with four repetitions each, totaling 20 plots, in a completely randomized design. Each plot measured $0.50 \times 0.55 \mathrm{~m}\left(0.27 \mathrm{~m}^{2}\right)$. Row spacing was maintained at $10 \mathrm{~cm}$ for all densities, with variations only to the spacement between plants. Thus, space between plants were $16.7 ; 11.1 ; 8.3 ; 6.7$; and 5.6 $\mathrm{cm}$, at the densities of $60,90,120,150$, and 180 plants $/ \mathrm{m}^{2}$, respectively.

Harvests began when plants presented at least one minituber larger than $30 \mathrm{~mm}, 50$ days after transplantation (DAT), and were carried out weekly (Farran \& Mingo-Castel, 2006) until the end of the growing cycle. At the last harvest (92 DAT), minitubers from all sizes were collected, but only tubers larger than $20 \mathrm{~mm}$ were accounted for in total yield. At each weekly harvest, we evaluated the number of minitubers/ plant (a) and $/ \mathrm{m}^{2}(\mathrm{~b})$; the fresh weight of minitubers/plant (c) and $/ \mathrm{m}^{2}$ (d); and the average fresh weight of minitubers (e).

A growth evaluation of plants was carried out at $70 \mathrm{DAT}$, in which the number of leaves/plant and $/ \mathrm{m}^{2}$, number of stems/plant and $/ \mathrm{m}^{2}$, main shoot 
length $(\mathrm{cm})$, root length $(\mathrm{cm})$, number of stolons/plant and $/ \mathrm{m}^{2}$ and number of initiated minitubers/plant and $/ \mathrm{m}^{2}$ were assessed from three central plants of each plot, in situ.

Data were submitted to the presupposition tests of the analysis of variance. When the normality presupposition was not attended, data (number of stems, leaves, stolons, and initiated tubers) were transformed into $\sqrt{x+0.5}$. Data were then submitted to analysis of variance (ANOVA) at $5 \%$ significance, and, when the $p$-value was significant, linear and quadratic regression analyses were performed using the software SISVAR ${ }^{\circledR}$ (Ferreira, 1998). The highest fit regression (adjusted $\mathrm{R}^{2}$ ) was chosen.

\section{Dormancy of potato minitubers}

The minitubers obtained at each harvest were placed in trays and separated according to plant densities and repetitions. Trays were placed inside a biochemical oxygen demand (BOD) chamber, at $23^{\circ} \mathrm{C}$, in the dark, until dormancy breaking. Dormancy breaking was determined as the date in which the minituber presented at least one sprout with more than $1 \mathrm{~mm}$ length.

The experimental design was completely randomized in a split-plot design, with four repetitions. The main plots were the harvesting dates (trays), and the subplots the planting densities $\left(60,90,120,150\right.$ and 180 plants $\left./ \mathrm{m}^{2}\right)$. Three evaluations were performed: at 126,140 , and 147 DAT, at which the number of minitubers that overcame dormancy was counted in proportion to total minitubers of each plot.

Data were transformed into arc. $\operatorname{sen} \sqrt{x}$ in order to obtain normal distribution and then submitted to analysis of variance (ANOVA) at $5 \%$ significance. When significant differences were detected, results were submitted to Tukey's test (harvesting dates) at $5 \%$ significance.

\section{RESULTS AND DISCUSSION}

\section{Growth}

At 70 DAT, plants at the density of 60 plants $/ \mathrm{m}^{2}$ presented twice as many stems as plants in the highest density (180 plants $\left./ \mathrm{m}^{2}\right), 2.50$ against 1.25 stems/plant (Figure 1A). However, despite the reduction per plant, plants in the highest planting density were able to compensate that loss per area, with 225 against $150 \mathrm{stems} / \mathrm{m}^{2}$ at the densities of 180 and 60 plants $/ \mathrm{m}^{2}$ (Figure 1B), respectively. A similar trend was observed for the number of leaves/plant and $/ \mathrm{m}^{2}$. Although plants at 60 plants $/ \mathrm{m}^{2}$ produced, on average, 4 more leaves than plants at 180 plants/ $\mathrm{m}^{2}$ (approximately 11 vs. 7 leaves/plant, respectively), the response was opposite for the number of leaves $/ \mathrm{m}^{2}$, ranging from 653 to 1238 leaves $/ \mathrm{m}^{2}$, at 60 and 180 plants $/ \mathrm{m}^{2}$, respectively (an increase of $89 \%$ ).

Main stem length was not affected by planting densities, withstanding at an average of $30.4 \mathrm{~cm} /$ plant $(p=0.53$; $\mathrm{CV}=18 \%$ ). Root length (Figure 1E) had an inverse correlation to planting density so that at 60 plants $/ \mathrm{m}^{2}$, the maximum root length reached $59.9 \mathrm{~cm}$ on average, $33 \%$ higher than recorded at 180 plants/ $\mathrm{m}^{2}(45.0 \mathrm{~cm})$.

The number of stolons/plant and $/ \mathrm{m}^{2}$ and the number of initiated minitubers/ plant were not affected by planting densities. An average of 0.8 stolons/ plant $(p=0.59 ; \mathrm{CV}=43 \%), 102$ stolons/ $\mathrm{m}^{2}(p=0.48 ; \mathrm{CV}=70 \%)$, and 3.35 initiated minitubers/plant $(p=0.47$; $\mathrm{CV}=23 \%$ ) were produced. However, the number of initiated minitubers $/ \mathrm{m}^{2}$ (Figure $1 \mathrm{~F}$ ) was directly correlated to the increase in planting density, going from $188 / \mathrm{m}^{2}$ (60 plants $\left./ \mathrm{m}^{2}\right)$ to 540 initiated minitubers $/ \mathrm{m}^{2}$ at 180 plants/ $\mathrm{m}^{2}$, an increase of $188 \%$.

With the increase in planting density, there was a reduction in the number of stems and leaves/plant, but not enough to reduce the number of leaves and stems $/ \mathrm{m}^{2}$. Thus, there was an increase of $90 \%$ in leaves $/ \mathrm{m}^{2}$, and $50 \%$ in stems/ $\mathrm{m}^{2}$, from 60 to 180 plants $/ \mathrm{m}^{2}$. Also, the reduction in the number of leaves and stems/plant did not compromise the canopy of plants to the point of reducing the number of initiated minitubers/plant. That resulted in a linear increase in the number of initiated minitubers $/ \mathrm{m}^{2}$ at higher planting densities, i.e., almost three times more initiated minitubers were recorded at 180 plants $/ \mathrm{m}^{2}$ than at 60 plants $/ \mathrm{m}^{2}$.

Final yield and yield through the growth cycle

The increment in planting density led to the reduction of the total number and fresh weight of minitubers/plant up to a specific density (Figures 2A and $2 \mathrm{C}$ ). The total number and fresh weight of minitubers went from 7.18 minitubers and $109 \mathrm{~g} / \mathrm{plant}$ at the density of 60 plants $/ \mathrm{m}^{2}$ to the minimum of 3.11 and $40.6 \mathrm{~g} / \mathrm{plant}$ at the densities of 146 and 144 plants $/ \mathrm{m}^{2}$, respectively. Distinctively, the total number and fresh weight of minitubers $/ \mathrm{m}^{2}$ (Figures 2B and 2D) correlated positively to planting densities. The highest total number of minitubers $/ \mathrm{m}^{2}$ occurred at the density of 180 plants $/ \mathrm{m}^{2}$, with 619 minitubers/ $\mathrm{m}^{2}$, and the lowest value, given by the equation vertex, at the density of 84.4 plants $/ \mathrm{m}^{2}$ with 397 minitubers $/ \mathrm{m}^{2}$ (a reduction of $36 \%$ ). The highest total fresh weight of minitubers $/ \mathrm{m}^{2}$ recorded was of $8.7 \mathrm{~kg} / \mathrm{m}^{2}$ at 180 plants $/ \mathrm{m}^{2}$, and the lowest was of $5.4 \mathrm{~kg} / \mathrm{m}^{2}$, at 97.8 plants $/ \mathrm{m}^{2}$ (also, a reduction of $36 \%$ ). The average fresh weight of minitubers did not vary as a function of planting densities, withstanding at $13.9 \mathrm{~g} /$ minituber.

The number of minitubers/plant (Figure 3A) was higher over the entire cycle in the population of 60 plants $/ \mathrm{m}^{2}$; however, differences to the densities of 120,150 , and 180 plants $/ \mathrm{m}^{2}$ were only observed at 71, 85 and 92 DAT. At 71 DAT, the density of 60 plants $/ \mathrm{m}^{2}$ had 18 harvested $\mathrm{g} /$ plant in comparison to $6.5 \mathrm{~g} / \mathrm{plant}$ of all the other densities, not differing only to the density of 150 plants $/ \mathrm{m}^{2}$ (Figure 3C). At 85 DAT, the density of 60 plants $/ \mathrm{m}^{2}$ had a higher harvested fresh weight of minitubers/ plant than 180 plants $/ \mathrm{m}^{2}$ and at 92 DAT higher than 120,150 , and 180 plants $/ \mathrm{m}^{2}$. There were differences in the number of minitubers $/ \mathrm{m}^{2}$ at 71 DAT when the density of 60 plants $/ \mathrm{m}^{2}$ differed from 90 , 150 , and 180 plants $/ \mathrm{m}^{2}$ (Figure $3 \mathrm{~B}$ ). The fresh weight of minitubers $\left(\mathrm{kg} / \mathrm{m}^{2}\right)$ also differed at 71 DAT, when the densities of 60,120 , and 150 plants $/ \mathrm{m}^{2}$ presented higher values than the density of 90 plants $/ \mathrm{m}^{2}$ (Figure 3D).

On average, 0.62 minitubers 


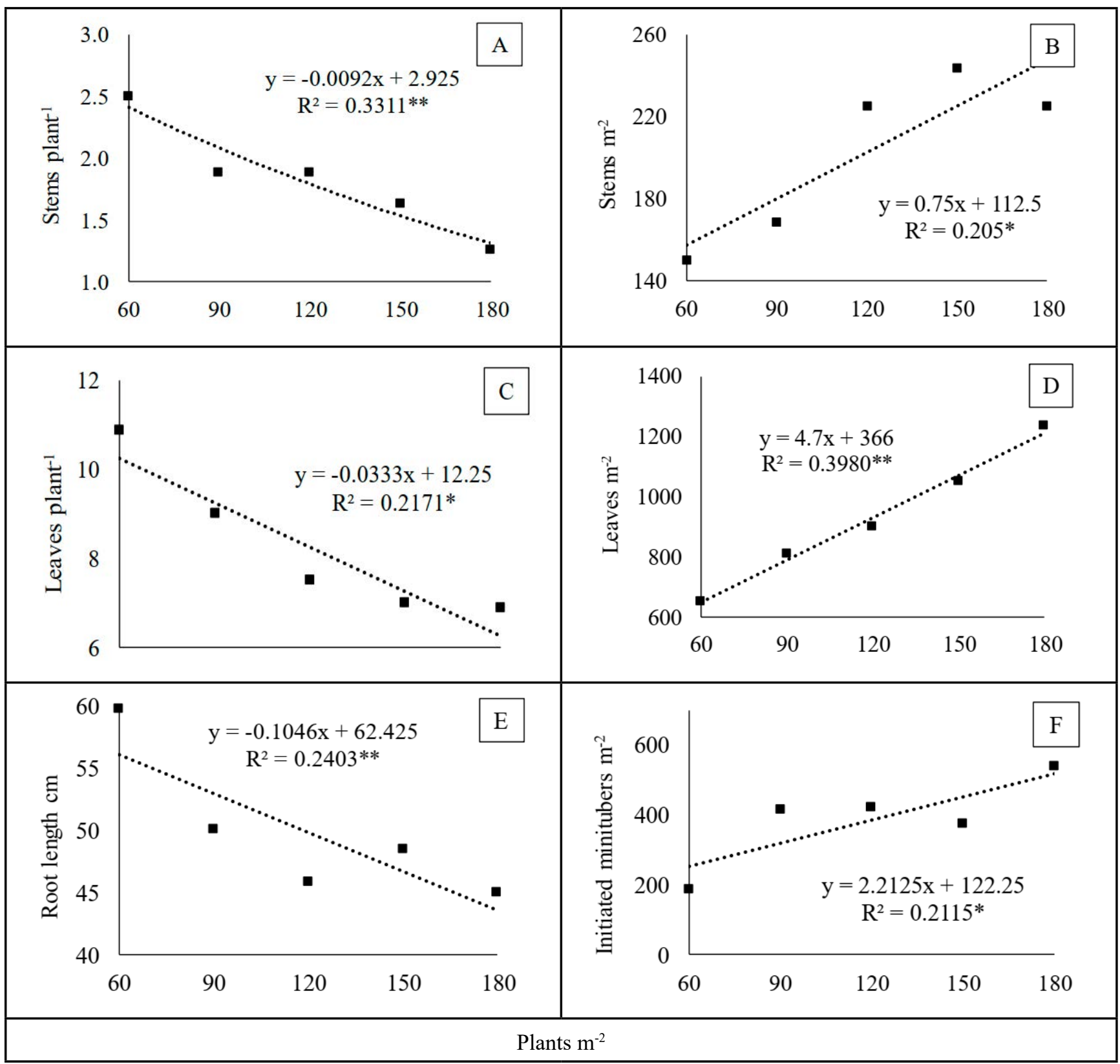

Figure 1. Number of stems/plant (A) and $/ \mathrm{m}^{2}(\mathrm{~B})$, number of leaves/plant (C) and $/ \mathrm{m}^{2}(\mathrm{D})$, root length (E), and number of initiated minitubers $/ \mathrm{m}^{2}(\mathrm{~F})$, of potato plants cv. Agata grown under different plant densities in aeroponic cultivation, at 70 days after transplantation. $*$ and $* *=$ significant at 5 and $1 \%$ by the ANOVA, respectively. Guarapuava, Unicentro, 2018.

weighing $8.81 \mathrm{~g} /$ plant, and 68 minitubers weighing $0.95 \mathrm{~kg} / \mathrm{m}^{2}$ were obtained at each harvest (Figure 3 ). The final harvest presented the highest number of harvested minitubers/plant and $/ \mathrm{m}^{2}$ (1.06 and 114 minitubers/plant and $/ \mathrm{m}^{-2}$, respectively), as minitubers larger than $20 \mathrm{~mm}$ were included. The highest fresh weight of minitubers/plant and $/ \mathrm{m}^{2}$ were recorded in the first harvest (50 DAT, $12.7 \mathrm{~g} / \mathrm{plant}$ and $1.37 \mathrm{~kg} / \mathrm{m}^{2}$, respectively). The harvests of 64 and 78 DAT presented the lowest values for the number and fresh weight of minitubers/ plant and $/ \mathrm{m}^{2}$

It is possible to infer two hypotheses on what lead to higher yield in the highest densities. The first is that plants cultivated in higher densities directed more photoassimilates/ plant to minitubers and that plants in lower densities allocated more photoassimilates/plant to their stems and leaves, at the expense of minituber production. This is corroborated by the fact that the lowest total number and fresh weight of minitubers/plant were recorded at around 145 plants $/ \mathrm{m}^{2}$, indicating a threshold for the reduction of yield/plant in the aeroponic system below the maximum studied population (180 plants $/ \mathrm{m}^{2}$ ). However, there was no threshold for the reduction of leaf number/plant: the lowest leaf number/ plant was recorded at the density of 180 plants $/ \mathrm{m}^{2}$.

The second hypothesis is that the increase in yield in higher populations may have been due to the greater utilization of incident solar radiation, given the increment in the number of leaves $/ \mathrm{m}^{2}$, and thus leaf area. This 


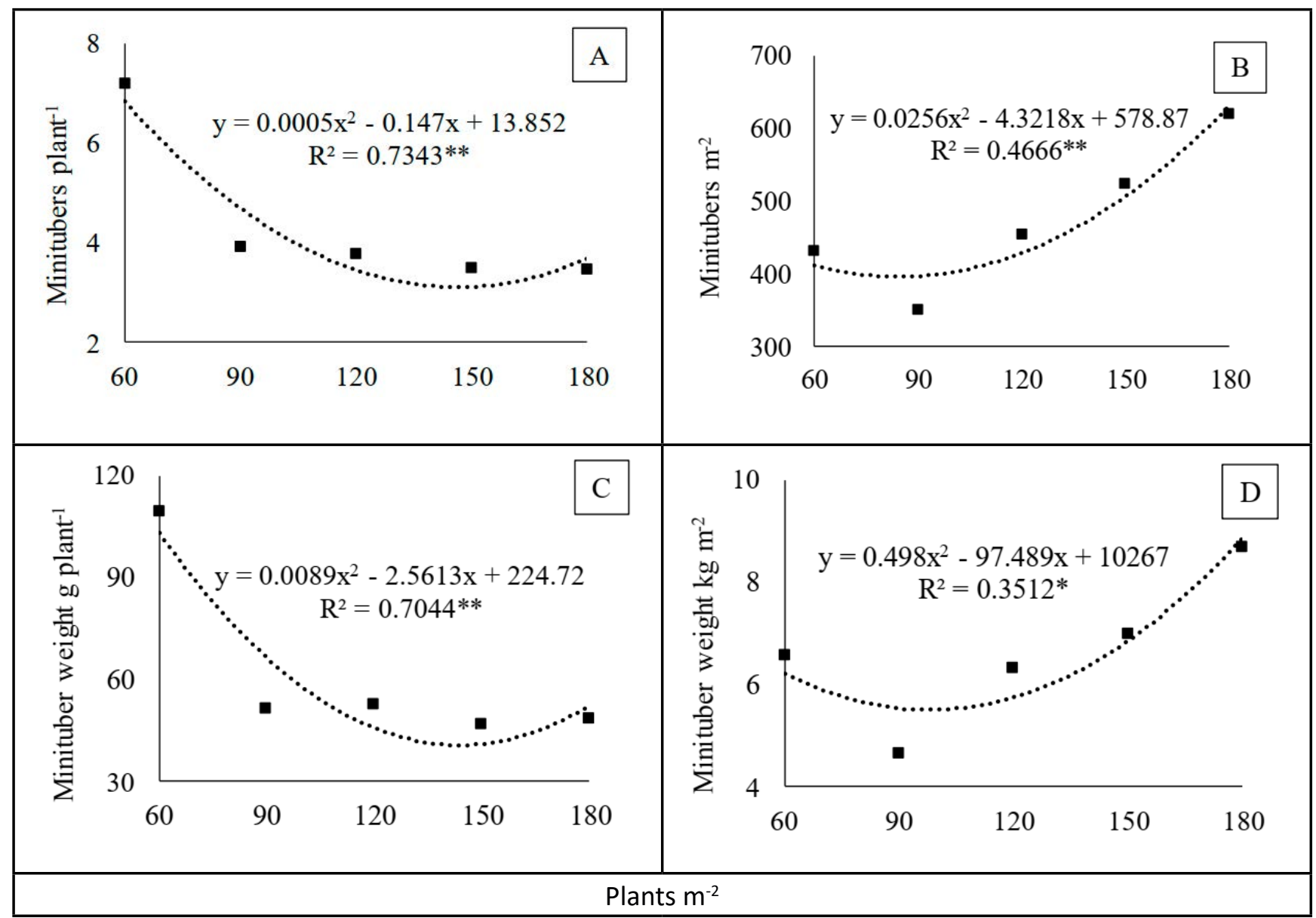

Figure 2. Total number of minitubers/plant (A) and $/ \mathrm{m}^{2}(\mathrm{~B})$, and total fresh weight of minitubers $/$ plant (C) and $/ \mathrm{m}^{2}(\mathrm{D})$, of potato plants cv. Agata grown under different plant densities in aeroponic cultivation, at 92 days after transplantation. * and **: significant at 5 and $1 \%$ by the ANOVA, respectively. Guarapuava, Unicentro, 2018.

hypothesis is corroborated by the analysis of the yield of treatments through the growth cycle. At the first harvests (from 50 to 64 DAT), there were no differences for the number and fresh weight of minitubers/plant among densities. Differences in these traits were only recorded later in the growth cycle, when the density of 60 plants $/ \mathrm{m}^{2}$, after complete foliar expansion, produced more tubers/plant than other treatments at 71,85 , and 92 DAT. Following that hypothesis, it is possible to infer that in higher densities, radiation interception and utilization was greater earlier in the cycle.

An inflection point on the number and fresh weight of minitubers $/ \mathrm{m}^{2}$ was not achieved in this study; thus, it is possible that the planting density of maximum yield $/ \mathrm{m}^{2}$, for the autumn cultivation in midwest Paraná, is even higher than the highest density tested (180 plants/ $\mathrm{m}^{2}$ ). However, with the laboratory- generated plantlet cost at about U $\$ 0.22$, minituber sales price at U\$ 0.11 , and the multiplication rate having reached 3.44 minitubers/plant at the density of 180 plants $/ \mathrm{m}^{2}$, it would be unlikely that the further increment of planting density resulted in higher profits to potato seed producers, if purchase costs as well as operational costs of planting and managing these new plantlets were taken in consideration.

Calori et al. (2018) investigated the effects of different electrical conductivities of the nutrient solution and planting densities on the yield of potato plants in the autumn season, north of Sao Paulo state. In their study, plants of cv. Agata developed a larger vegetative structure/plant than what was registered even in the lowest plant densities of our experiment, an average of 4.5 stems and 36.1 leaves/plant (Calori et al., 2018), as opposed to 2.5 stems and 10.9 leaves/plant at 60 plants $/ \mathrm{m}^{2}$ in our study. A maximum multiplication rate of 1303 type III minitubers $/ \mathrm{m}^{2}$ (diameter of at least $30 \mathrm{~mm}$ ) at 100 plants $/ \mathrm{m}^{2}$ and EC of $2.1 \mathrm{dS} \mathrm{m}^{-1}$ was recorded (Calori et al., 2018). In the present study, the maximum multiplication rate was of 613 minitubers $/ \mathrm{m}^{2}$, at 180 plants $/ \mathrm{m}^{2}$.

However, it is worth noticing that, in spite of the difference in multiplication rate to other studies, the minituber fresh weight $/ \mathrm{m}^{2}$ of our study is within standards or higher than found in the literature for the aeroponic cultivation of potatoes. Despite reporting even higher multiplication rates, of up to 1445 minitubers $/ \mathrm{m}^{2}$, Wang et al. (2018) obtained a maximum fresh weight of minitubers $/ \mathrm{m}^{2}$ of $3.8 \mathrm{~kg}$. The maximum fresh weight of minitubers $/ \mathrm{m}^{2}$ of the present study was $8.7 \mathrm{~kg}$, up to four times the recorded in other studies (Wang et al., 2017, 2018). Thus, the major difference in multiplication rate/ $\mathrm{m}^{2}$ is due to the harvest criterion adopted 


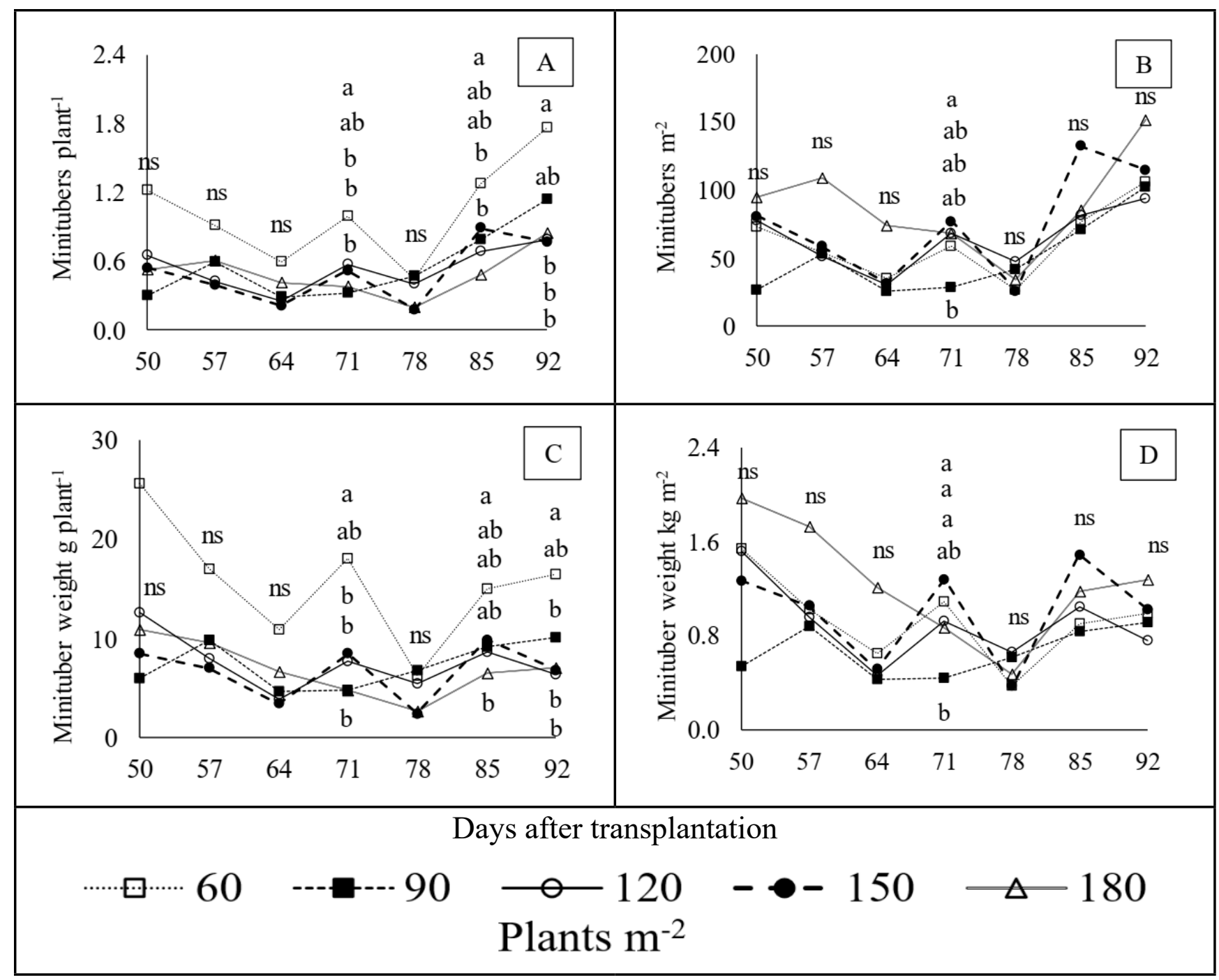

Figure 3. Number of minitubers/plant (A) and $/ \mathrm{m}^{2}(\mathrm{~B})$, and fresh weight of minitubers/plant (C) and $/ \mathrm{m}^{2}(\mathrm{D})$, in 7 harvests from potato plants cv. Agata grown under different plant densities in aeroponic cultivation. Means with different letters in each day after transplantation differ by Tukey's test at 5\% significance. Guarapuava, Unicentro, 2018.

by Brazilian potato producers (type III minitubers), that results in a high average fresh weight: $13.9 \mathrm{~g} /$ minituber in the present study, as opposed to 2.8 $\mathrm{g} /$ minituber in the study by Wang et al. (2018).

One of the challenges for potato seed minituber production in aeroponics is making it economically viable, and able to grow for more than a cycle in the same year across environments (MateusRodríguez et al., 2013). One way to do it would be by adding supplementary lighting to plants in periods of lower radiation incidence; however, more studies on this subject are necessary to determine the cost-benefit ratio and the efficiency of such practice.

Farran \& Mingo-Castel (2006) observed an interaction among planting densities and the frequency of sequential harvests on the yield of minitubers, obtaining up to 802 minitubers $/ \mathrm{m}^{2}$ with weekly harvests at 60 plants $/ \mathrm{m}^{2}$, and up to 500 minitubers $/ \mathrm{m}^{2}$ in harvests performed every 10 days, at 100 plants/ $\mathrm{m}^{2}$. Therefore, the harvest interval may also have an impact on yield under the conditions of the currently studied region, and studies regarding this trait are required.

\section{Dormancy of minitubers}

There were no differences in the dormancy period of minitubers in relation to planting densities in the aeroponic system (Figure 4A), in any of the evaluations. However, differences in the dormancy period of minitubers obtained at different harvesting dates were observed (Figure 4B).

At the first evaluation, performed 76 days after the first harvest in the aeroponic system (126 DAT), 14\% of the minitubers from the first harvest (50 DAT) had broken dormancy, while minitubers from the $3^{\text {rd }}$ and $5^{\text {th }}$ harvest (64 and 78 DAT, respectively) were still dormant (Figure 4B). At the second evaluation, at $140 \mathrm{DAT}$, all minitubers from the first harvest had broken dormancy, while only $51.4 \%$ of the minitubers harvested at 64 DAT and $57.7 \%$ of the minitubers harvested at 78 DAT overcame it. At the third evaluation (147 DAT), there were no differences among treatments, as all minitubers had sprouted.

The period from harvest until full overcoming of dormancy of minitubers 


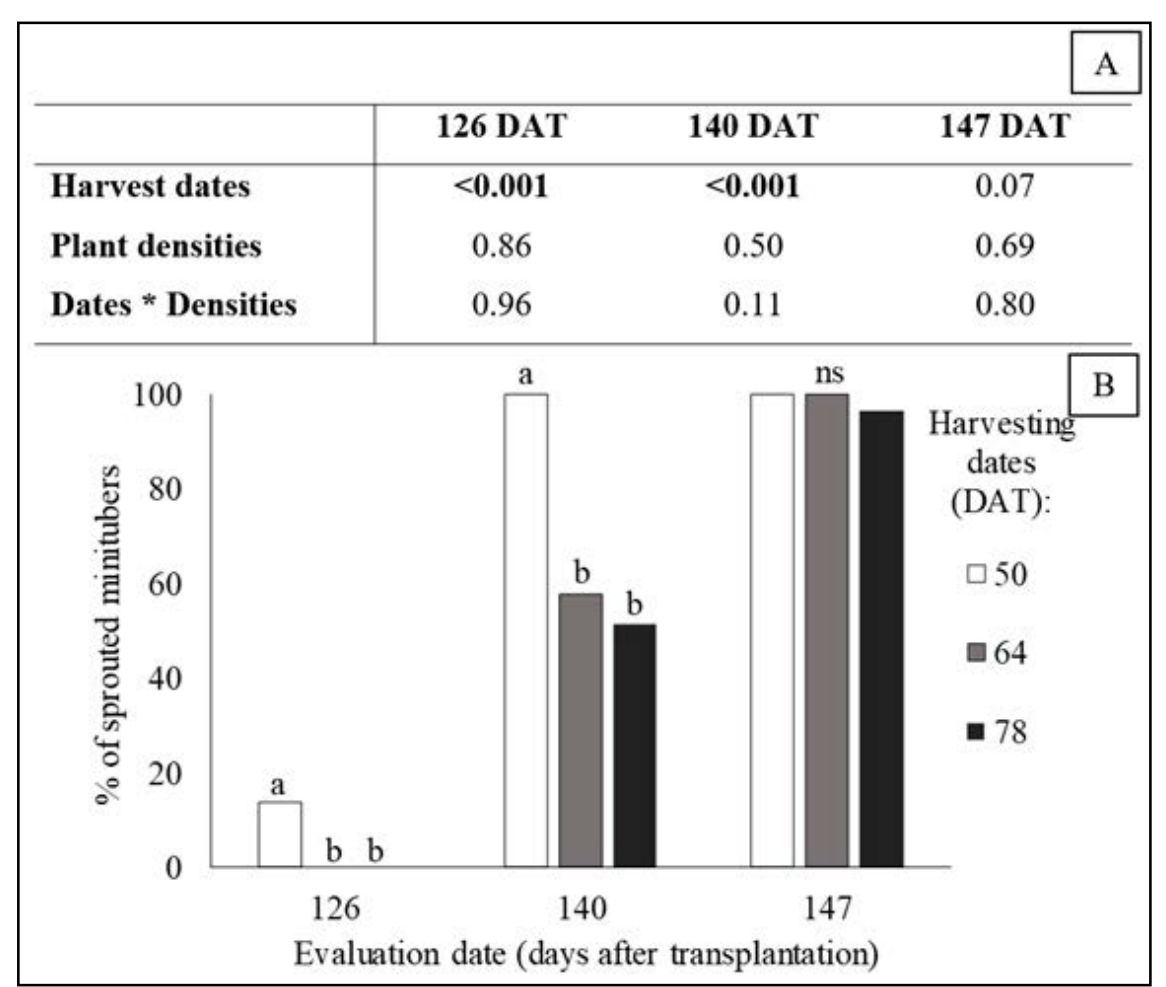

Figure 4. P-value of analysis of variance (ANOVA) for the percentage of dormancy break of minitubers harvested in different dates $(50,64$ and 78 days after transplantation) and planting densities $\left(60,90,120,150\right.$ and 180 plants $\left./ \mathrm{m}^{2}\right)$ in three evaluated dates: 126,140 and 147 days after transplantation (A); and Tukey's test on the percentage of dormancy break of minitubers as a function of harvesting dates (B). Columns with different letters in each day after transplantation differ by Tukey's test at 5\% significance. Guarapuava, Unicentro, 2018.

harvested at 50, 64, and 78 DAT was 90 , 83 , and 69 days, respectively. Therefore, a reduction of 7 and 21 days from the harvests at 64 and 78 DAT was observed in comparison to the dormancy period of minitubers harvested at 50 DAT. Our study is the first to our knowledge that evaluates the effect of harvesting dates in aeroponics on the dormancy period of potato minitubers.

Rykaczewska (2016) observed that the yield of potato crops formed from minitubers of cv. Ametyst harvested in aeroponics responds in a quadratic form to harvesting dates. That is, there is variation due to the physiological age of harvested minitubers, in which the ideal minituber would be obtained at intermediary harvests of the aeroponic cycle (for maximum yield in the following field planting). In the present study, minitubers obtained from different harvests likewise possess different dormancy periods. This may be due to differences in the hormone and nutrient contents of minitubers.

Potato plants in the vegetative development phase have a high content of gibberellins in their tissues, which induce stem, leaf and stolon development, at the expense of tuber formation (Xu et al., 1998; Wang et $a l ., 2018)$. At the tuberization phase, the hormonal balance shifts, increasing the concentration of the abscisic acid and ethylene hormones, which induce tuber formation (Xu et al., 1998). That difference in the concentration of hormones may also occur in tubers, and, observed that the content of gibberellins exerts a fundamental role in sprouting induction (Shibairo et al., 2006), it can alter the dormancy period of minitubers harvested at different phases of the growing cycle.

Tuber dormancy is set at tuber initiation (Claassens \& Vreugdenhil, $2000)$. In the aeroponic growth cycle, most tuber formation occurs concomitantly at the beginning of the cycle, however, tuber filling is disproportionate, i.e., some tubers are prioritized by the mother plant and fill up to harvest size sooner. Therefore, the difference in measured dormancy among harvesting dates may be due to a longer filling period of the tubers harvested last. In addition, tuber dormancy can be shortened by colder weather during tuber development (Suttle, 2007), which is expected in the final harvests of the autumn cultivation.

Minitubers in different dormancy and sprouting stages may then lead to varying yields at the next field planting, due to variations in their emergence speed or even in the number of stems originated per minituber. It is not yet known if aeroponically produced potato minitubers harvested in different dates, after dormancy break, have similar yield performance in field production.

In our study, we verified that the number of stems, leaves, and the number and fresh weight of minitubers/plant reduced when planting density was increased from 60 to 180 plants $/ \mathrm{m}^{2}$. However, the number of stems, leaves, initiated minitubers, and the number and fresh weight of minitubers $/ \mathrm{m}^{2}$ increased when planting density was increased from 60 to $180 \mathrm{plants} / \mathrm{m}^{2}$. The maximum yield of type III minitubers $(>30 \mathrm{~mm}$, $13.9 \mathrm{~g}$ ) was $613 \mathrm{~m}^{-2}$, obtained at the density of 180 plants $/ \mathrm{m}^{2}$. Plant density did not affect the dormancy of harvested minitubers, but harvesting date did. Latter harvesting dates reduced the dormancy period. Minitubers harvested at 78 and 64 days after transplanting sprouted 21 and seven days earlier than those harvested at 50 days after transplanting.

\section{ACKNOWLEDGEMENTS}

The authors thank 'Fundação Araucária' for the funding provided for this research.

\section{REFERENCES}

ABBA - Associação Brasileira de Batata. 2010. Brasil - Atuais variedades. Batata Show 28.

ANDRADE-PIEDRA, JL; KROMANN, P; OTAZÚ, V (eds). 2015. Manual para la producción de semilla de papa usando aeroponía: Diez años de Experiencias en Colombia, Ecuador y Perú. Centro Internacional de la Papa (CIP), Instituto Nacional de Investigaciones Agropecuarias (INIAP), Corporación Colombiana de 
Investigación Agropecuaria (CORPOICA). Quito, Ecuador. 267p.

CALORI, AH; FACTOR, TL; FELTRAN, JC; WATANABE, EY; MORAES, CC; PURQUÉRIO, LFV. 2017. Electrical conductivity of the nutrient solution and plant density in aeroponic production of seed potato under tropical conditions (winter/spring). Bragantia 76: 23-32.

CALORI, AH; FACTOR, TL; FELTRAN, JC; WATANABE, EY; MORAES, CC; PURQUERIO, LFV. 2018. Seed potato minituber production in an aeroponic system under tropical conditions: electrical conductivity and plant density. Journal of Plant Nutrition 41: 2200-2209.

CEPEA/ESALQ/USP. 2019. Especial Batata 2019. HortiFruti Brasil 18: 46p.

CEPII. 2020. BACI: International trade database at the product-level. Available at $O E C$ - The observatory of economic complexity. $<$ https:// oec.world/en/>. Accessed on March 19 $9^{\text {th }}, 2020$.

CLAASSENS, MMJ; VREUGDENHIL, D. 2000. Is dormancy breaking of potato tubers the reverse of tuber initiation? Potato Research 43: 347-369.

FACTOR, TL. 2007. Produção de minitubérculos de batata-semente em sistemas hidropônicos NFT, DFT e aeroponia. Jaboticabal: UNESP. $120 \mathrm{p}$ (Ph.D. thesis).

FACTOR, TL; ARAUJO, JA; KAWAKAMI, FP; IUNCK, V. 2007. Produção de minitubérculos básicos de batata em três sistemas hidropônicos. Horticultura Brasileira 25: 82-87.

FAO. 2008. International year of the potato. Food and agriculture organization. Available at <http://www.fao.org/potato-2008/en/>. Accessed on July $20^{\text {th }}, 2019$.

FAO. International year of the potato. 2008. Food and agriculture organization. Available at <http://www.fao.org/potato-2008/en/>. Accessed on July 20 ${ }^{\text {th }}$, 2019. FAO. 2020. Food and agriculture organization's statistics.
Available at $<$ http://www.fao.org/faostat/ en/\#home $>$. Accessed on March $20^{\text {th }}, 2020$.

FARRAN, I; MINGO-CASTEL, A. 2006. Potato minituber production using aeroponics: Effect of plant density and harvesting intervals. American Journal of Potato Research 83: 47-53.

FERREIRA, DF. 1998. Sisvar - sistema de análise de variância para dados balanceados. Lavras: UFLA. 19p.

IBGE-LSPA - Instituto Brasileiro de Geografia e Estatística. 2020. Levantamento Sistemático da Produção Agricola. Available at $<\mathrm{https}$ :// sidra.ibge.gov.br/home/lspa/brasil $>$. Accessed on March $20^{\text {th }}, 2020$.

MATEUS-RODRÍGUEZ, JR; HAAN, DES; ANDRADE-PIEDRA, JL; MALDONADO, L; HAREAU, G; BARKER, I; CHUQUILLANQUI, C; OTAZÚ, V; FRISANCHO, R; BASTOS, C; PEREIRA, AS; MEDEIROS, CA; MONTESDEOCA, F; BENÍTEZ, J. 2013. Technical and economic analysis of aeroponics and other systems for potato mini-tuber production in Latin America. American Journal of Potato Research 90: 357-368.

MEDEIROS, CAB; ZIEMER, AH; DANIELS, J; PEREIRA, AS. 2002. Produção de sementes pré-básicas de batata em sistemas hidropônicos. Horticultura Brasileira 20: 110-114.

MUTHONI, J; SHIMELIS, H; MELIS, R. 2013. Alleviating potato seed tuber shortage in developing countries: Potential of true potato seeds. Australian Journal of Crop Science 7: 1946-1954.

OTAZÚ, V. 2010. Manual on quality seed potato production using aeroponics. Lima, Peru: CIP. 44p.

RYKACZEWSKA, K. 2016. Field performance of potato minitubers produced in aeroponic culture. Plant, Soil and Environment 62: 522-526.

SASA - Science \& Advice for Scottish Agriculture.
2020. The European cultivated potato database. 2020. Available at <http://www. europotato.org/>. Accessed on February $28^{\text {th }}$, 2020.

SEAB - Secretaria de Estado da Agricultura e do Abastecimento / DERAL Departamento de Economia Rural. Olericultura: análise da conjuntura agropecuária. Parana, 2019, 21 p. Available at $<\mathrm{http}: / /$ www.agricultura. pr.gov.br/sites/default/arquivos_restritos/ files/documento/2019-09/olericultura_2019_ v1.pdf $>$. Accessed on March 20 ${ }^{\text {th }}, 2020$.

SHIBAIRO, S; DEMO, P; KABIRA, J; GILDEMACHER, P; GACHANGO, E; MWALIMU, M; NYANKANGA, R; CHEMINING'WA, G; NARLA, R. 2006. Effects of gibberellic acid (GA3) on sprouting and quality of potato seed tubers in diffused light and pit storage conditions. Journal of Biological Sciences 6: 723-733.

SUTTLE, JC. 2007. Dormancy and sprouting. In: VREUGDENHIL, D; BRADSHAW, J; GEBHARDT, C; GOVERS, F; MACKERRON, D; TAYLOR, M; ROSS, H (eds). Potato Biology and Biotechnology. [s.1.] Elsevier, p.287-309.

WANG, CC; WANG, XY; WANG, KX; HU, JJ; TANG, MX; HE, W; VANDER ZAAG, P. 2018. Manipulating aeroponically grown potatoes with gibberellins and calcium nitrate. American Journal of Potato Research 95: 351-361.

WANG, K; HE, W; AI, Y; HU, J; XIE, K; TANG, M; WANG, Y; ZAAG, PV. 2017. Optimizing seed potato production by aeroponics in China. Philippine Journal of Crop Science 42: 69-74.

XU, X; LAMMEREN, AAM; VERMEER, E; VREUGDENHIL, D. 1998. The role of gibberellin, abscisic acid, and sucrose in the regulation of potato tuber formation in vitro. Plant Physiology 117: 575-584. 